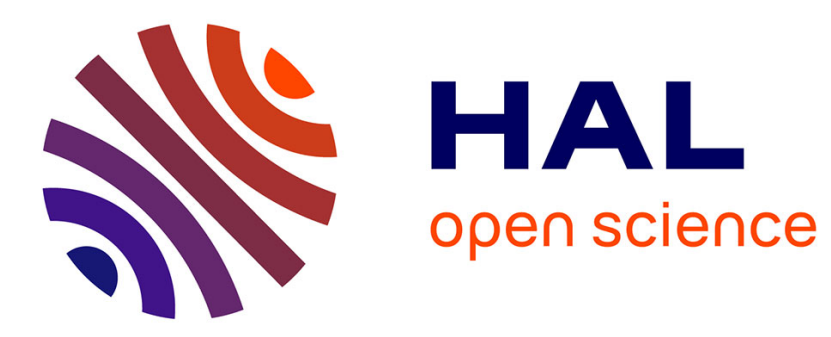

\title{
Competition between surface and subsurface rolling contact fatigue failures of nitrided parts: A Dang Van approach
}

\author{
E. Bossy, J.P. Noyel, X. Kleber, F. Ville, C. Sidoroff, S. Thibault
}

\section{- To cite this version:}

E. Bossy, J.P. Noyel, X. Kleber, F. Ville, C. Sidoroff, et al.. Competition between surface and subsurface rolling contact fatigue failures of nitrided parts: A Dang Van approach. Tribology International, 2019, 140, 10.1016/j.triboint.2019.105888 . hal-02405414

\author{
HAL Id: hal-02405414 \\ https://hal.science/hal-02405414
}

Submitted on 20 Dec 2021

HAL is a multi-disciplinary open access archive for the deposit and dissemination of scientific research documents, whether they are published or not. The documents may come from teaching and research institutions in France or abroad, or from public or private research centers.
L'archive ouverte pluridisciplinaire HAL, est destinée au dépôt et à la diffusion de documents scientifiques de niveau recherche, publiés ou non, émanant des établissements d'enseignement et de recherche français ou étrangers, des laboratoires publics ou privés.

\section{(ㄷ)(1) $\$$}

Distributed under a Creative Commons Attribution - NonCommerciall 4.0 International 


\title{
Competition between surface and subsurface rolling contact fatigue failures of nitrided parts: a Dang Van approach
}

\author{
$<$ E. BOSSY $\rangle^{1,2,3,4} ;\langle\text { J-P. NOYEL }\rangle^{3} ;\langle\text { X. KLEBER }\rangle^{2} ;\langle\text { F. VILLE }\rangle^{1} ;\langle\text { C.SIDOROFF }\rangle^{4,5}$; \\ $<$ S. THIBAULT $>4,6$ \\ 1 <Univ Lyon, INSA-Lyon, CNRS UMR5259, LaMCoS, F-69621, France> \\ $2<$ Univ Lyon, INSA-Lyon, UMR CNRS 5510, MATEIS, France> \\ 3 <Univ Lyon, ECAM-Lyon, INSA-Lyon LabECAM, F-69005, France> \\ 4 <Institut de Recherche Technologique, Matériaux, Métallurgie et Procédés, Metz, France> \\ 5 <NTN-SNR, NTN Group, Annecy, France> \\ ${ }^{6}<$ SAFRAN Tech, SAFRAN Group, Magny-les-Hameaux, France>
}

\section{Abstract}

Mechanical contacts in rolling element bearings and gears are increasingly loaded nowadays. In high temperature applications, surface treatments such as gas-nitriding are used to increase their rolling contact fatigue life. This study focuses on the prediction of the location of crack initiation for gas-nitrided steels subjected to rolling contact fatigue taking into account the material property gradients induced by the nitriding process. Several approaches based on the Dang Van criterion are compared to experimental data to find the most reliable prediction model.

\section{Introduction}

Downsizing, higher efficiency and design optimization of aeronautical gears and rolling element bearings (REB) induce higher loading of mechanical contacts, thus higher risk of surface and/subsurface initiated rolling contact fatigue (RCF) and irreversible surface damage. These damages are largely studied [1-4] and can be of different types. Among them surface micropitting or wear, and surface-initiated or subsurface initiated spalling. For a given metallurgy, these failure mechanisms are mainly affected by lubrication aspects (film thickness, type of base oil, additive packages, ageing, etc.) [5,6], the sliding speed and the induced contact stresses [7]. The present work focuses on the influence of contact stresses on the initiation of damage.

In order to understand and better predict RCF failures, numerical models were developed. Previous studies, like the ones of Lundberg and Palmgren [8] or Ioannides and Harris [9] for REB, paved the way for current numerical RCF investigations. Mechanical contact stresses being multiaxial, multiaxial fatigue criterion such as the Dang Van one [10] are well suited for RCF modelling, as shown in many studies [11-18]. However, these studies mainly focus on conventional through hardened bearing steels.

Gears and REB manufacturers use case hardening to increase the RCF resistance of their components with complex processes such as gaseous nitriding. This thermochemical treatment enhance the surface properties of case hardened steels by increasing hardness and introducing compressive residual stresses [19]. It creates a continuous gradient of properties between the bulk and the surface. Studies of 32CrMoV13 nitrided steels subjected to RCF were led by Tonicello [20] or Weil [21] who used the Dang Van criterion. Le [22] experimentally investigated RCF initiated cracks and their propagation.

Most of these studies focus on the effect of the Hertzian contact pressure which mainly concerns sub-surface initiated damage due to the depth of the related stresses [23]. Surface 
features of the contacting bodies (roughness, dents...) comparatively influences more surface initiated damage. Coulon [24], Labiau [25] or Morales [26] propose semi-analytical ways to evaluate stress concentration due to surface features for dry or EHL contacts. These stress risers are located close to the surface and often exceed subsurface stresses, leading to surface initiated damage.

The present study focuses on the location of RCF crack initiation for deep gas-nitrided $32 \mathrm{CrMoV} 13$ steel for mechanical components depending on contact conditions. At first, a finite element (FE) model for dented rolling contact is built. Then crack initiation location is identified using Dang Van and Tresca shear stress criteria. An analysis of material properties due to the gas-nitriding process is led where materials parameters are based on empirical measurements. Finally, experimental data and numerical results are compared.

\section{RCF Modelling}

A FE model similar to the Noyel's one [27] is developed for this study. It consists of a 2D mesoscopic modelling of grains in an infinite body (Figure 1) with the plane strain hypothesis. The dimension of the infinite body are linked to the contact semi-length a. As studied by Noyel [28], a body 50 times wider than a, the contact semi-length, which is similar to an infinite body. At the edge of the body, perpendicular displacements are prescribe to 0 . The simulation are performed in quasi-static with quadratics elements. Therefore, the stress tensor only has five components. The grains are considered as isotropic. Simulations are made for a dry contact, in order to analyse the most severe case for damage and to optimize computational times [29].

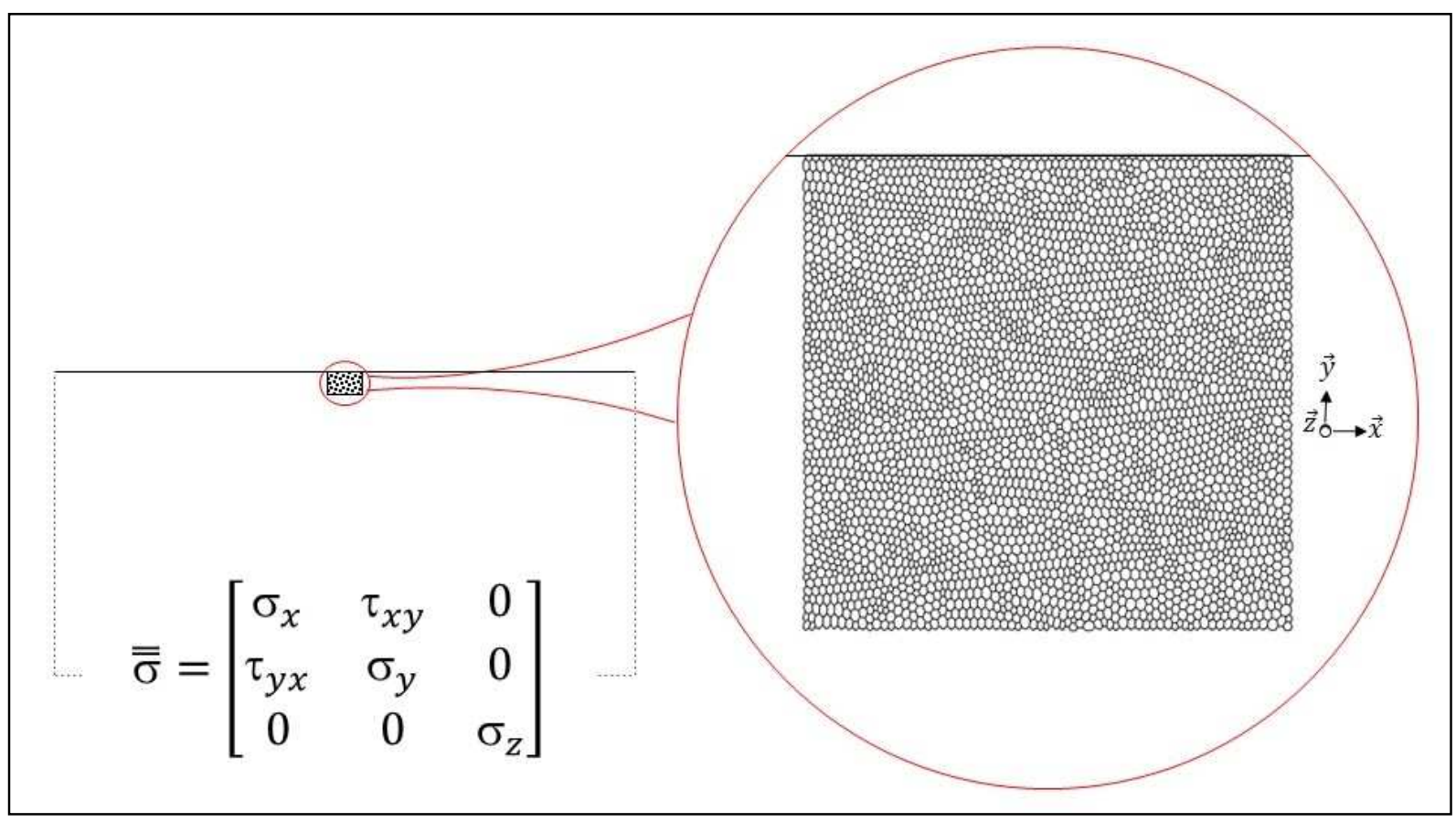

Figure 1: Simulation summary

To apply a contact stress on grains, a Hertzian contact pressure is moving on the top surface. The classical Hertzian pressure [30], shown in Figure 2, is representative for two perfect smooth contacting bodies. In the present study, only a 2D pressure field is considered, which is representative of linear contacts [23]. 


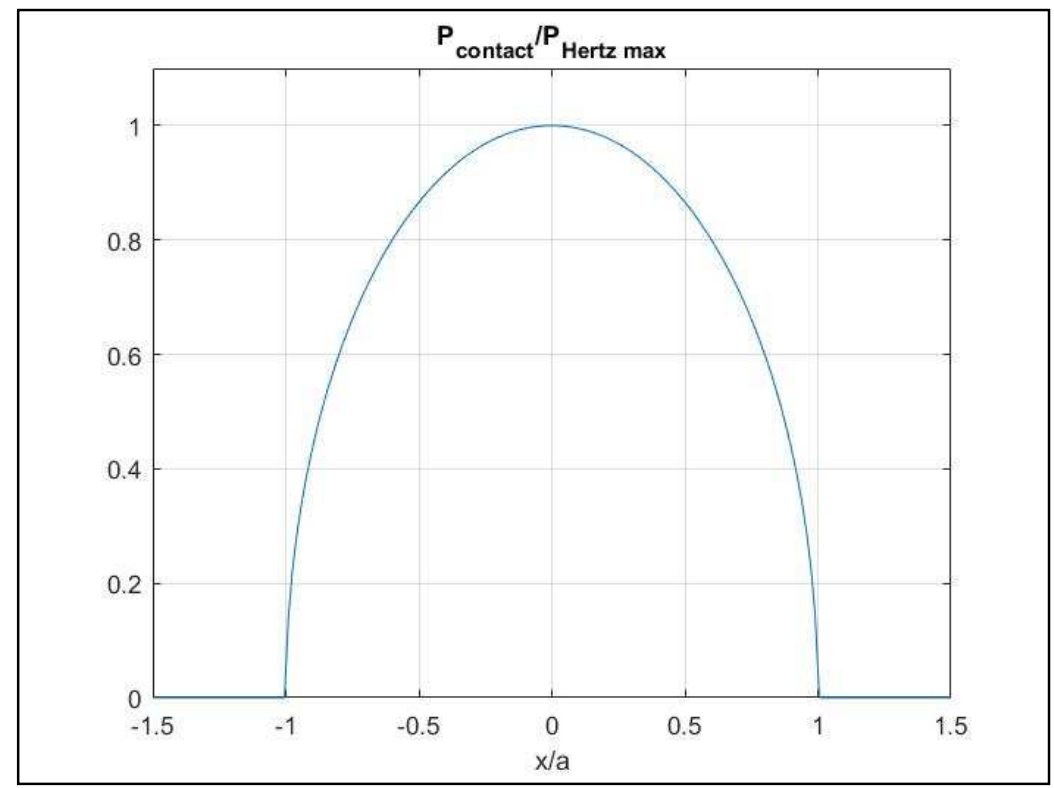

Figure 2 : Hertzian contact pressure

However, real surface geometry affects the contact pressure distribution. Manufacturing defects or dents caused by particle contamination are strongly affecting the classical Hertzian pressure by inducing stress concentrations. This paper focuses on debris dents observed in both gears and REBs. Figure 3 shows a measured surface of a dented REB inner ring. Dents are commonly more severe than the surrounding surface roughness due to their shoulder amplitudes. To simplify the model, an analytical formula (1) is used to keep only the dent shape and filter out small wave-length roughnesses [24,29]. In the formula, $\mathrm{d}_{\mathrm{th}}$ is the depth of the dent, $\mathrm{R}_{\mathrm{x}}$ the curvature radius in $\vec{x}$ direction, $\varphi$ the diameter of the dent and $\mathrm{K}$ a numerical factor for the height of the dent shoulders.

$$
y_{\text {dent }}(x, z)=\frac{d_{t h} R_{x}}{a^{2}} * e^{-K \frac{\left(\frac{x}{a}\right)^{2}+\left(\frac{z}{a}\right)^{2}}{4\left(\frac{\varphi}{a}\right)^{2}}} * \cos \left(\frac{\sqrt{\left(\frac{x}{a}\right)^{2}+\left(\frac{z}{a}\right)^{2}}}{\frac{\varphi}{a}}\right)
$$

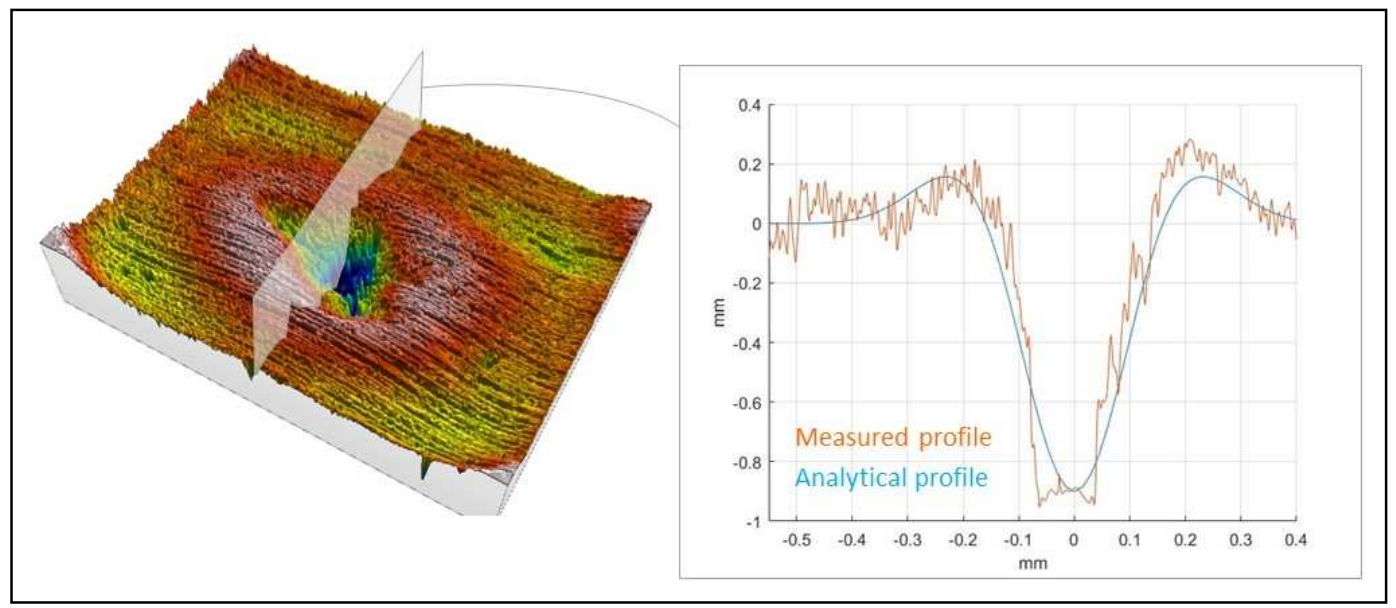

Figure 3 : Measured and analytical profiles

The methodology developed in [24,29] is used to calculate contact stress induced by dent shoulders. The resulting contact stress is composed of the classic Hertzian contact pressure 
and an overpressure due to dent, as show in Figure 4. The overpressure value depends on dimensionless parameters relative to the dent dimensions and some contact parameters.

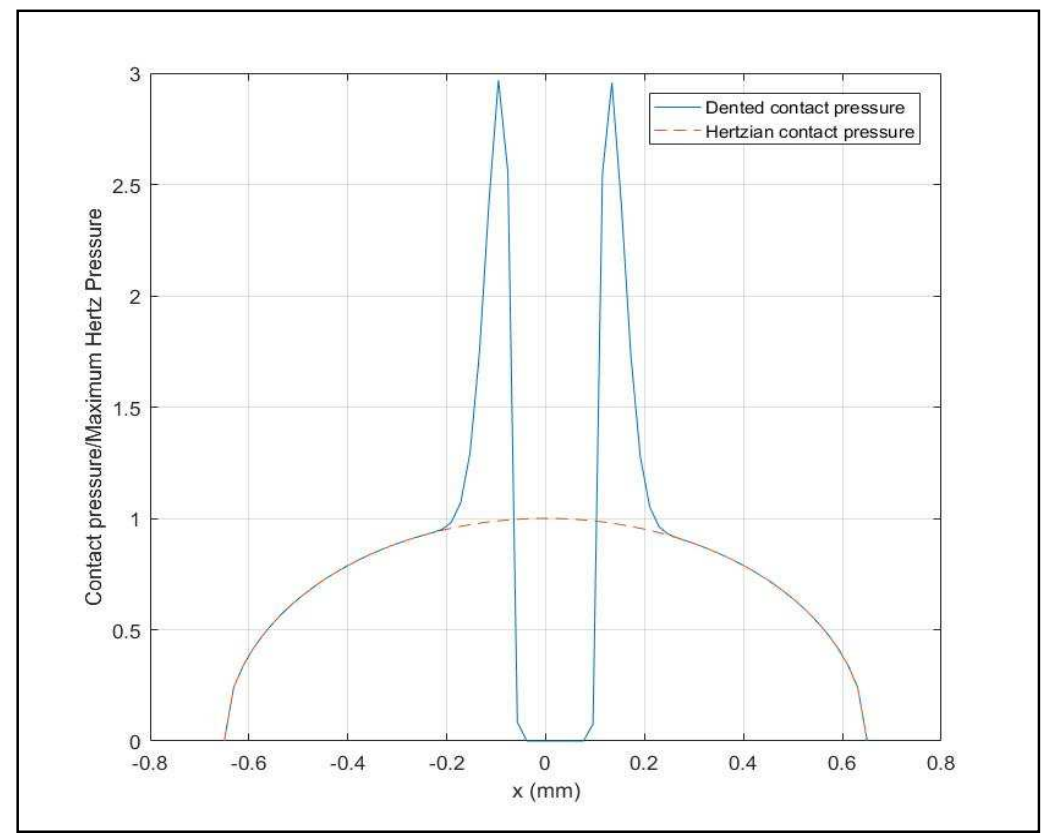

Figure 4 : Dented contact pressure

This overpressure will create surface located over-stresses [31]. Contact parameters leading to Figure 4 pressure field are given in Table 1. They correspond to the experiments presented in paragraph 3. Figure 5 shows the Tresca shear stress (2) for a classic Hertzian contact and a dented one.

$$
\tau_{\text {Tresca }}=\frac{\left|\sigma^{I}-\sigma^{I I I}\right|}{2}
$$

Where $\sigma^{\mathrm{I}}$ and $\sigma^{\mathrm{III}}$ are the maximum and the minimum principal stresses of the stress tensor.

Both simulations use the same contact parameters (Table 1), the only difference being the presence of a dent in the second one. The stresses are due to the pressure distributions shown in Figure 4.

\begin{tabular}{|c|c|c|}
\hline$P_{\text {Hertz }}$ & maximal Hertzian pressure & $2.1 \mathrm{GPa}$ \\
\hline$a$ & contact semi-length & $0.62 \mathrm{~mm}$ \\
\hline$d t h$ & dent depth & $37 \mu \mathrm{m}$ \\
\hline$\phi$ & dent diameter & $250 \mu \mathrm{m}$ \\
\hline \multicolumn{2}{|c}{ Table 1 : Simulation contact parameters }
\end{tabular}




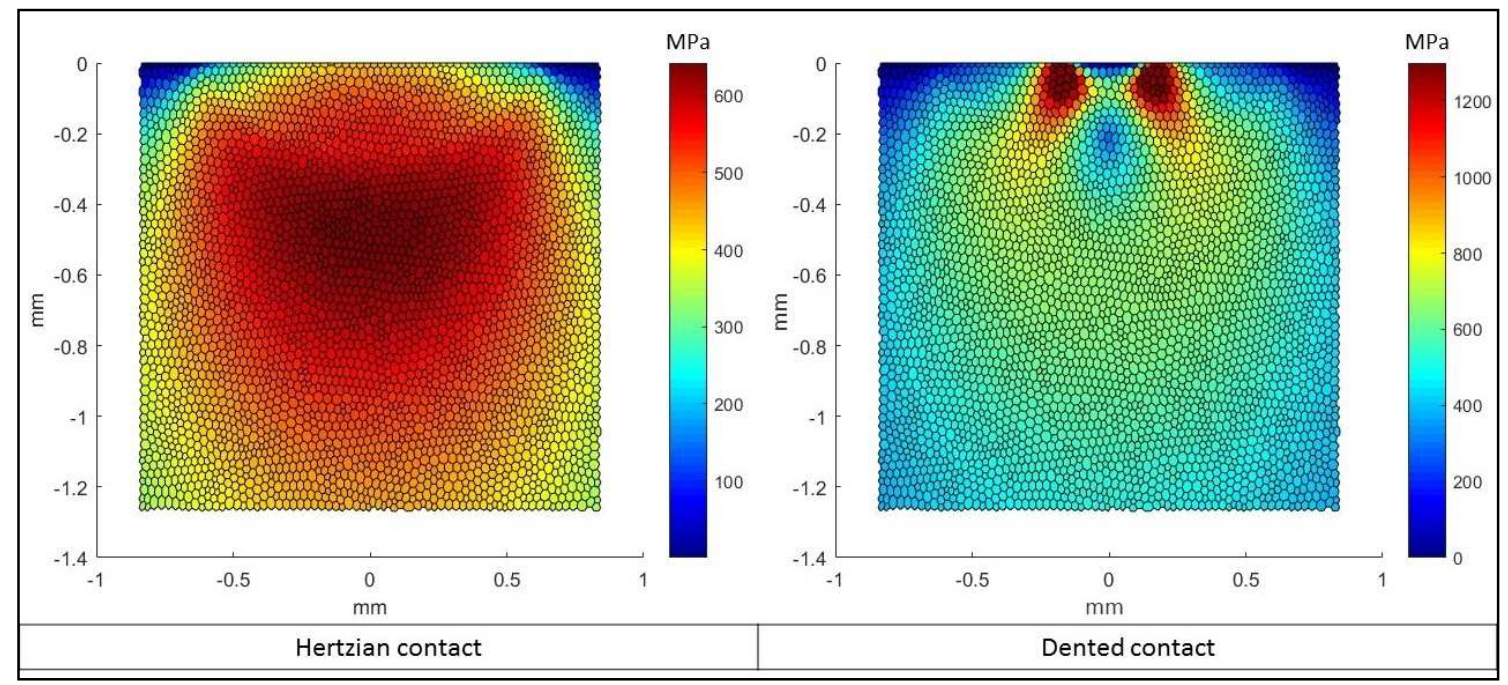

Figure 5 : Tresca shear stresses with dent centred in $x=0$

Since this study focuses on rolling contact, the applied load in the simulation goes from left to right as shown in Figure 6.

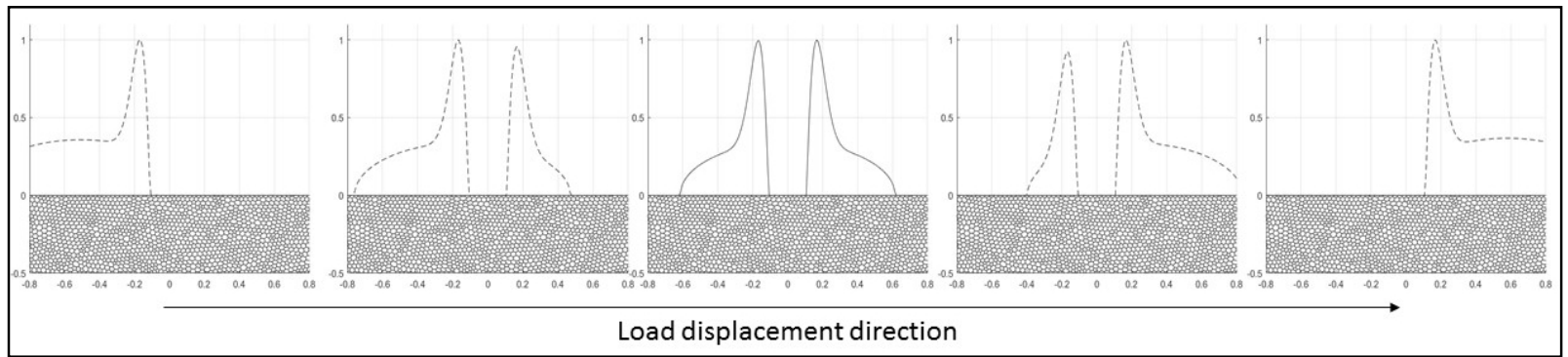

Figure 6: Load displacement and resulting pressure fields

\section{Comparison with experimental data}

Twin-disc experiments are often used to simulate RCF of two contacting bodies [32,33]. Crack propagation in nitrided steel was studied using a twin-disc test rig by Le [22], Tests were performed in two steps (initiation and propagation ) under the contact conditions given in Table 1. During the initiation step, a dented crowned disc was used to initiate surface cracks on the flat counter-disc. Then, during propagation step, a new crowned smooth disc replaced the dented one. Figure 7 shows a comparison between Tresca shear stresses and a metallographic observation of the cracks after Nital etching from [34]. The black dotted lines locate the depth of the dent-induced over-stresses, while the white one corresponds to the start of the dark etching area (DEA). Surface overstresses due to dent relate to the crack but not to the DEA, which is induced by deeper stresses induced by the Hertzian contact pressure. 


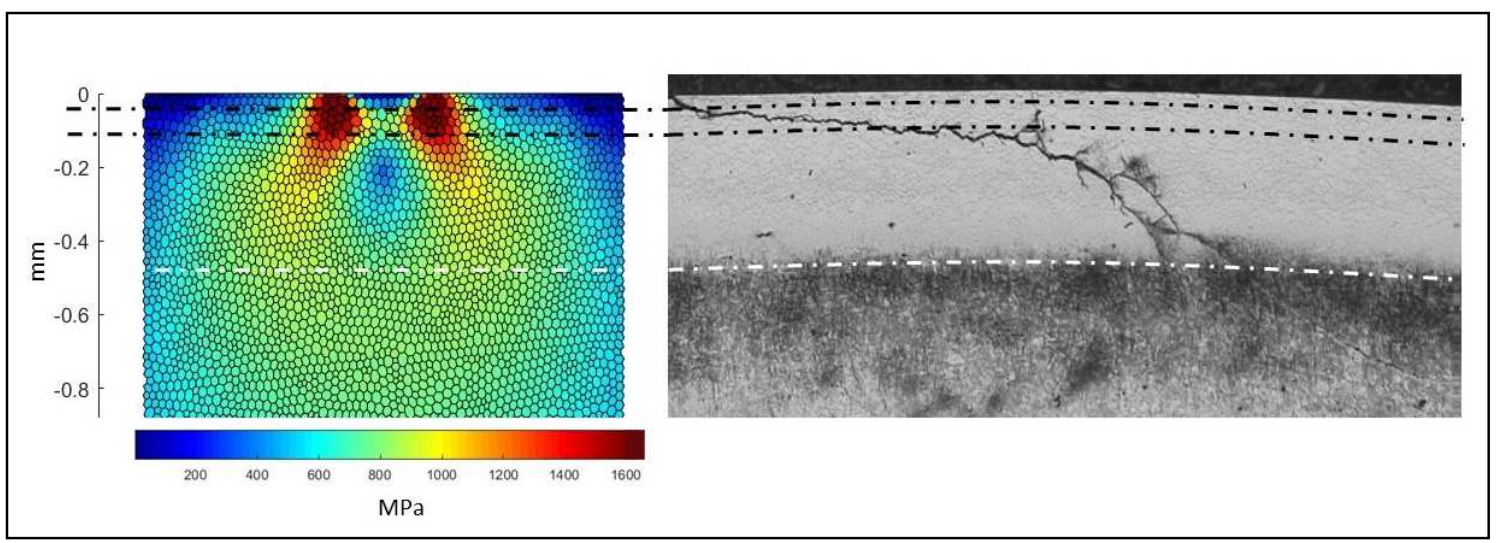

Figure 7: Tresca shear stresses compared to experimental observations - dent centred in $x=0$

\section{Dang Van criterion}

Since a comparison with the Tresca shear stresses cannot explain all experimental observations such as DEA, the Dang Van criterion [10] is used. It is a multiaxial fatigue criterion at a mesoscopic scale based on the stabilized stresses (2). Once the macroscopic stresses are calculated using the present FE model, mesoscopic ones are obtained following equation hereafter:

$$
[s]_{\text {mesoscopic }}(t)=[S]_{\text {macroscopic }}(t)-\left[\rho^{*}\right]
$$

Macroscopic stresses are calculated with the FE model presented before. The deviatoric part, $[S]_{\text {macroscopic }}$, is then calculated using (3).

$$
[S]_{\text {macroscopic }}(t)=[\sigma]_{\text {macroscopic }}(t)-P_{\text {hydro }}(t)
$$

With

$$
P_{\text {hydro }}(t)=\frac{\operatorname{trace}\left([\sigma]_{\text {macroscopic }}(t)\right)}{3}
$$

The principle to obtain the mesoscopic shear stress is to calculate $\rho^{*}$, the centre of minimum circumscribed hypersphere to the deviatoric stress path [35] and to subtract it from $[S]_{\text {macroscopic }}(2)$. Once the mean stress is obtained, $\tau_{\text {mesoscopic }}$ is given by calculating the Tresca shear stress of $[s]_{\text {mesoscopic }}(t)$, in (5).

$$
\tau_{\text {mesoscopic }}(\mathrm{t})=\frac{\left|\sigma_{\text {mesoscopic }}^{I}(t)-\sigma_{\text {mesoscopic }}^{I I I}(t)\right|}{2}
$$

Where $\sigma_{\text {mesoscopic and }}^{\mathrm{I}} \sigma_{\text {mesoscopic }}^{\mathrm{III}}$ are the maximum and the minimum principal stresses of $[s]_{\text {mesoscopic }}(t)$. Crack initiates if the following criterion is verified

$$
\max _{\text {time }}\left[f_{D V}(t)\right] \geq \beta
$$

$$
\text { with } f_{D V}(t)=\tau_{\text {mesoscopic }}(t)+\alpha \cdot P_{\text {hydro }}(t)
$$


Where $\alpha$ and $\beta$ are material parameters given by:

$$
\begin{gathered}
\alpha=\frac{3 \tau_{\text {reverse torsion }}}{\sigma_{\text {reverse bending }}}-\frac{3}{2} \\
\beta=\tau_{\text {reverse torsion }}
\end{gathered}
$$

With: - $\tau_{\text {reverse torsion }}$, the reverse torsion fatigue limit,

- $\sigma_{\text {reverse bending }}$, the reverse bending one.

Numerical values of these material parameters are discussed later.

Since the simulations are made at the mesoscopic scale, the criterion is calculated for each grain, and not for each element. This way the stresses are the same over one grain (ASTM grain size 8). Figure 8 shows the evolution of the Dang Van function (7), in the classical $\left(P_{\text {hydrostatic }}, \tau_{\text {mesoscopic }}\right.$ frame for different identified grains.

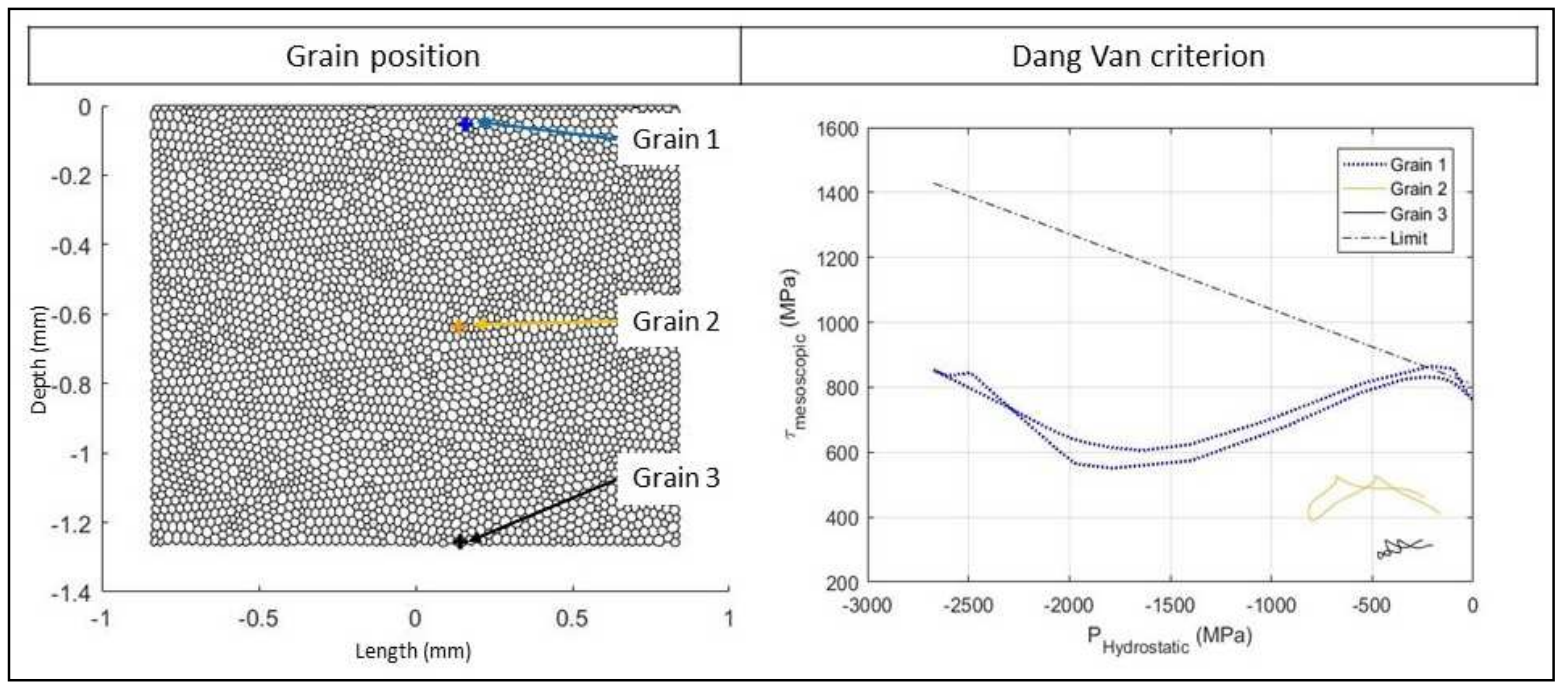

Figure 8: Dang Van criterion for different identified grains

The grain close to the surface has a larger path than the other ones and is close to the limit. As the criterion is a comparison to the $\beta$ value, a dimensionless formulation is proposed (10). If the value is equal or greater than one, crack initiation may occur:

$$
\frac{f_{D V}(t)}{\beta}=\frac{\max _{\text {time }}\left[\tau_{\text {mesoscopic }(t)}+\alpha \cdot P_{\text {hydro }}(t)\right]}{\beta}
$$

Figure 9 shows the evolution of $f_{D V} / \beta$ for the identified grains. 


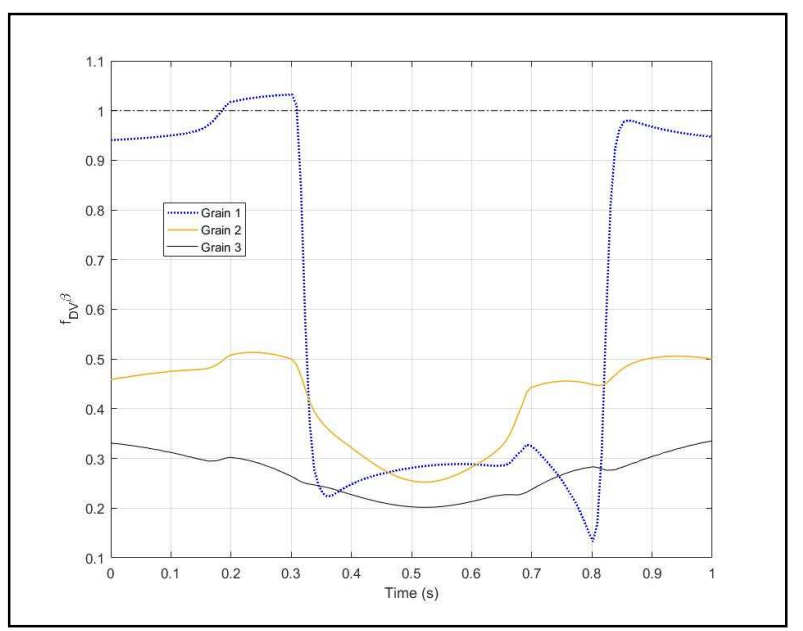

Figure 9 : Dimensionless Dang Van function

Since the Dang Van criterion is the maximum value over the loading cycle, only the maximum value is kept for each grain (Table 2). Grain 1 value is higher since its loading path exceed the limit defined by the material parameters described here after.

\begin{tabular}{|r|c|c|c|}
\cline { 2 - 4 } \multicolumn{1}{c|}{} & Grain 1 & Grain 2 & Grain 3 \\
\hline Dimensionless Dang Van criterion & 1.03 & 0.51 & 0.34 \\
\hline
\end{tabular}

Since the Dang Van criterion predicts crack initiation if the value of $\frac{f_{D V}(t)}{\beta}$ exceed 1 , the scale of all figures showing the criterion are limited to 1 at the maximum in order to highlight the initiations zones.

\section{Material properties}

Since the gas-nitriding process enhances surface properties, the limits are not constant with depth [19]. Reverse bending fatigue limits are estimated for both bulk material and nitrided surface. The surface fatigue limit was estimated using staircase method on notched samples to be sure that crack initiates on the surface and not in the bulk [36]. Values are given in Table 3. The values for bulk material are very close to those measured by Barralis and Castex [37]. As shown before, the Dang Van criterion is based on two material properties, the reverse bending fatigue limit $\sigma_{\text {reverse bending }}$ and the reverse torsion fatigue limit $\tau_{\text {reverse torsion. }}$. Barralis and Castex [37] measured both and found a ratio between the two values close to $\sqrt{3}$ for $32 \mathrm{CrMoV} 13$ steel. This factor was used to calculate the torsion fatigue limit with the reverse bending limit.

\begin{tabular}{|c|c|c|}
\hline Fatigue limits & Bulk material & Surface \\
\hline$\sigma_{\text {reverse bending }}$ & $700 \mathrm{MPa}$ & $1400 \mathrm{MPa}$ \\
\hline Calculated $\tau_{\text {reverse torsion }}$ & $404 \mathrm{MPa}$ & $808 \mathrm{MPa}$ \\
\hline \multicolumn{2}{|c|}{ Table 3: Fatigue limits } \\
\hline
\end{tabular}

Figure 10 shows the cartography of the Dang Van criterion considering that all the grains have either bulk (a) or surface (b) material properties. Since the bulk material properties are 
lower, the value of the criterion is higher. Using only these properties, the mechanical component would be over-dimensioned to be able to withstand the considered loading. Using only the surface material properties on the other hand could lead to an under-dimensioned component with a high risk of failure initiated around the white dotted line, which corresponds to the depth of maximum Hertzian stress. At this depth, bulk properties lead to the prediction of crack initiation whereas surface ones do not.

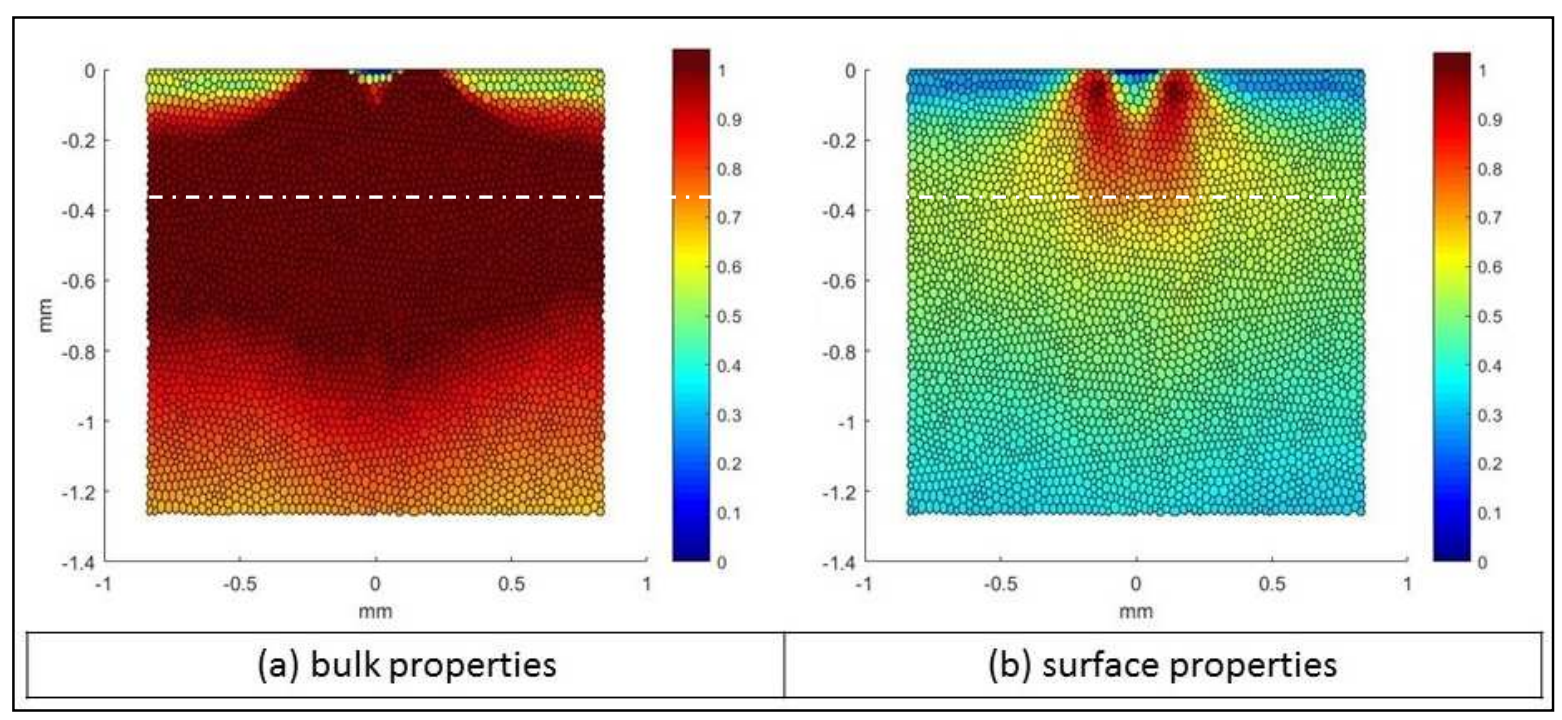

Figure 10 : Dang Van criterion for different material properties

Figures 11 and 12 show a comparison of the previous criterion with the metallographic observation in Figure 7. On one hand, the values of the criterion, Figure 11, predict a crack initiation within all the observed area and are therefore not suitable for the prediction of crack initiation location. One the other hand, Figure 12 does not explain the presence of DEA in the sub-surface area.

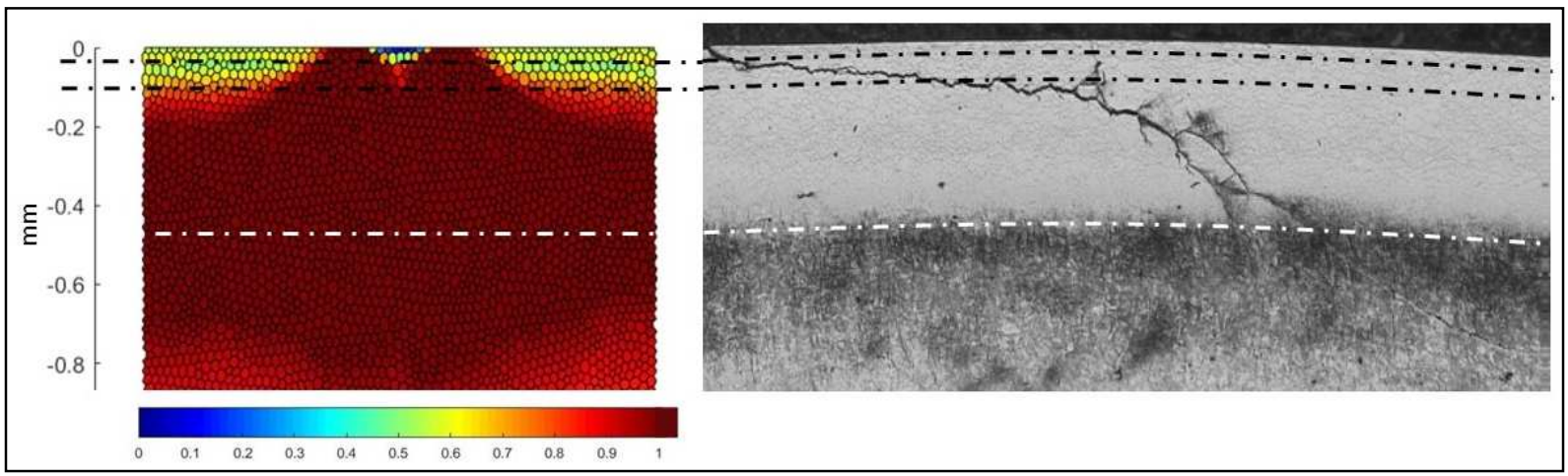

Figure 11: Dang Van criterion for bulk properties compared to experimental observations 


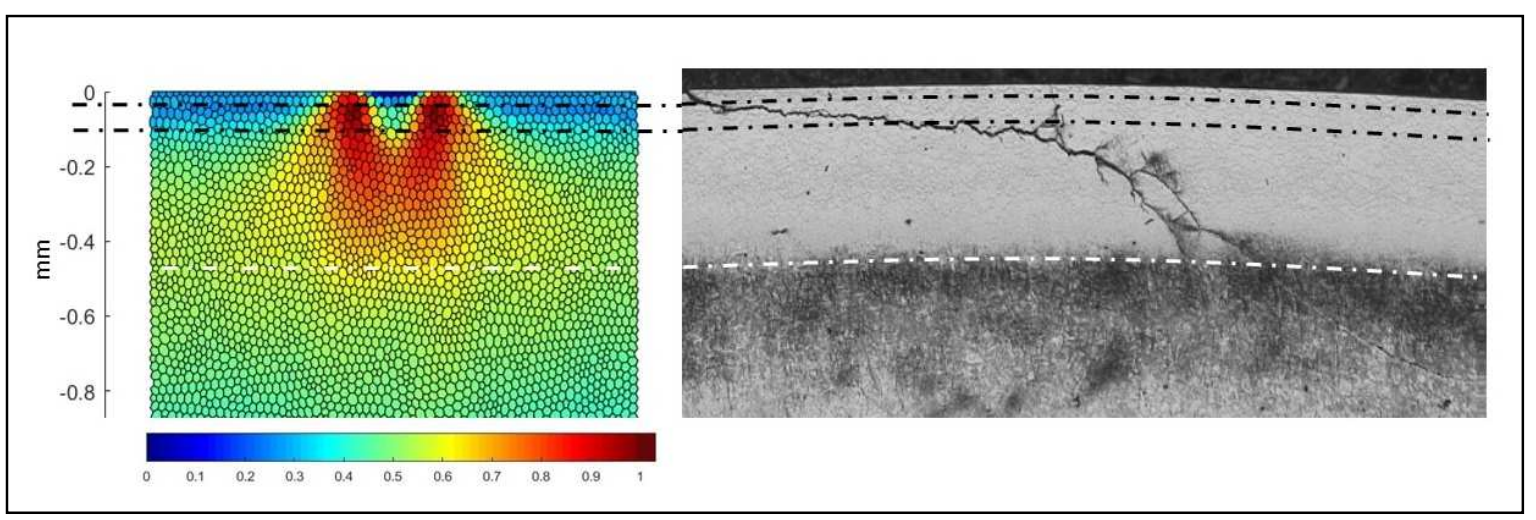

Figure 12 : Dang Van criterion for surface properties compared to experimental observations

\section{Nitriding modelling}

Gas nitriding leads to a property gradient between the two boundaries as discussed in paragraph 5. The evolution of hardness with depth is given in Figure 13.

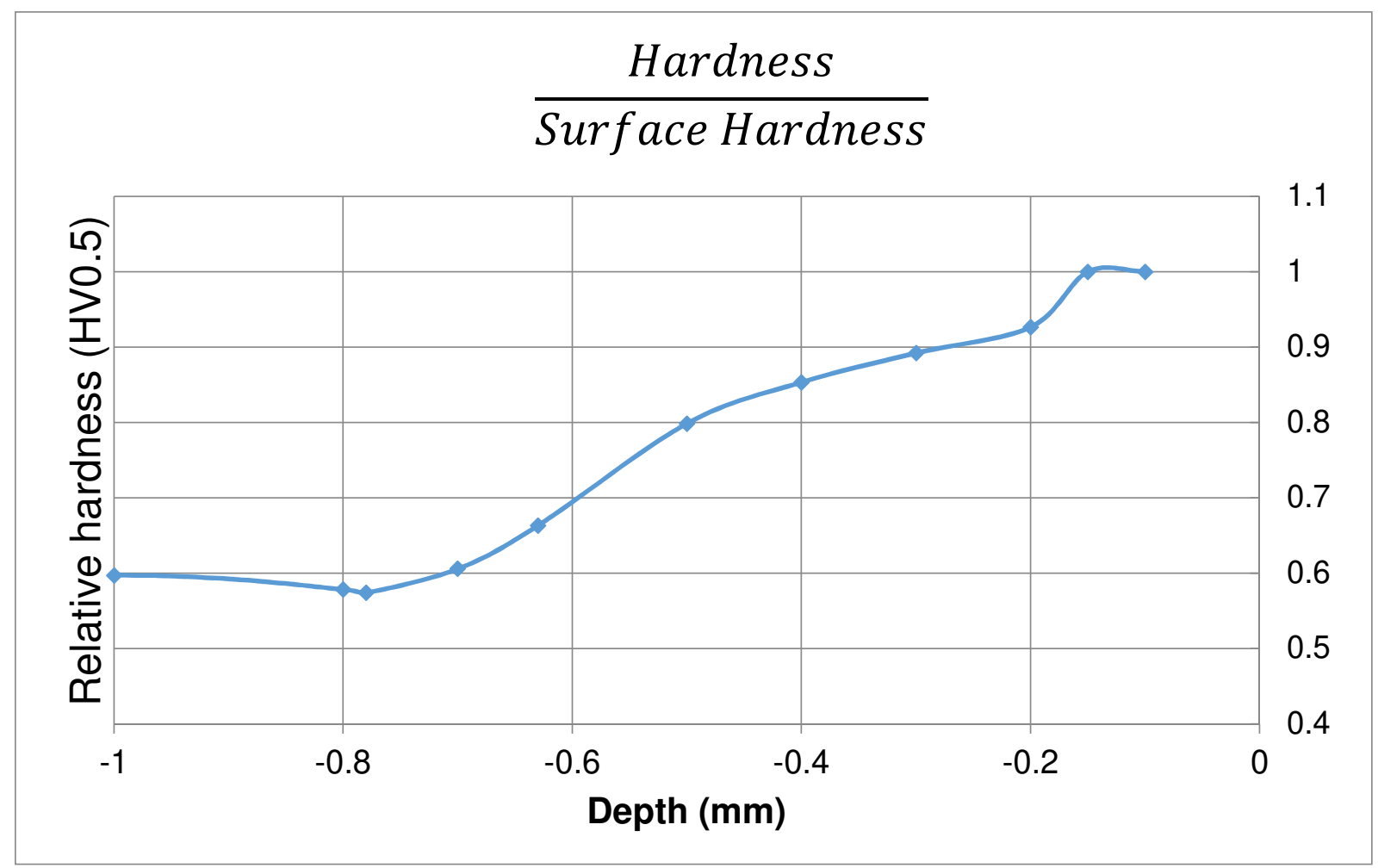

Figure 13 : Relative hardness of nitrided steel

Figure 14(a) is the micro-yield stress for $32 \mathrm{CrMoV} 13$ nitrided steel measured by Girodin [38]. The evolution between bulk and surface properties is steep but still continuous. A similar gradient is used to modify both both $\sigma_{\text {reverse bending }}$ and $\tau_{\text {reverse torsion }}$ with depth as shown is Figure 14(b). The mathematical expressions linking these three parameters are given in equations (12) and (13). Since $\sigma_{\text {reverse bending }}$ at the surface and in the bulk are $400 \mathrm{MPa}$ higher than the micro-yield stress, a simple addition is used here.

$$
\sigma_{\text {reverse bending }}(y)=\sigma_{\text {Micro Yield stress }}(y)+400
$$




$$
\tau_{\text {reverse torsion }}(y)=\frac{\sigma_{\text {reverse bending }}(y)}{\sqrt{3}}
$$

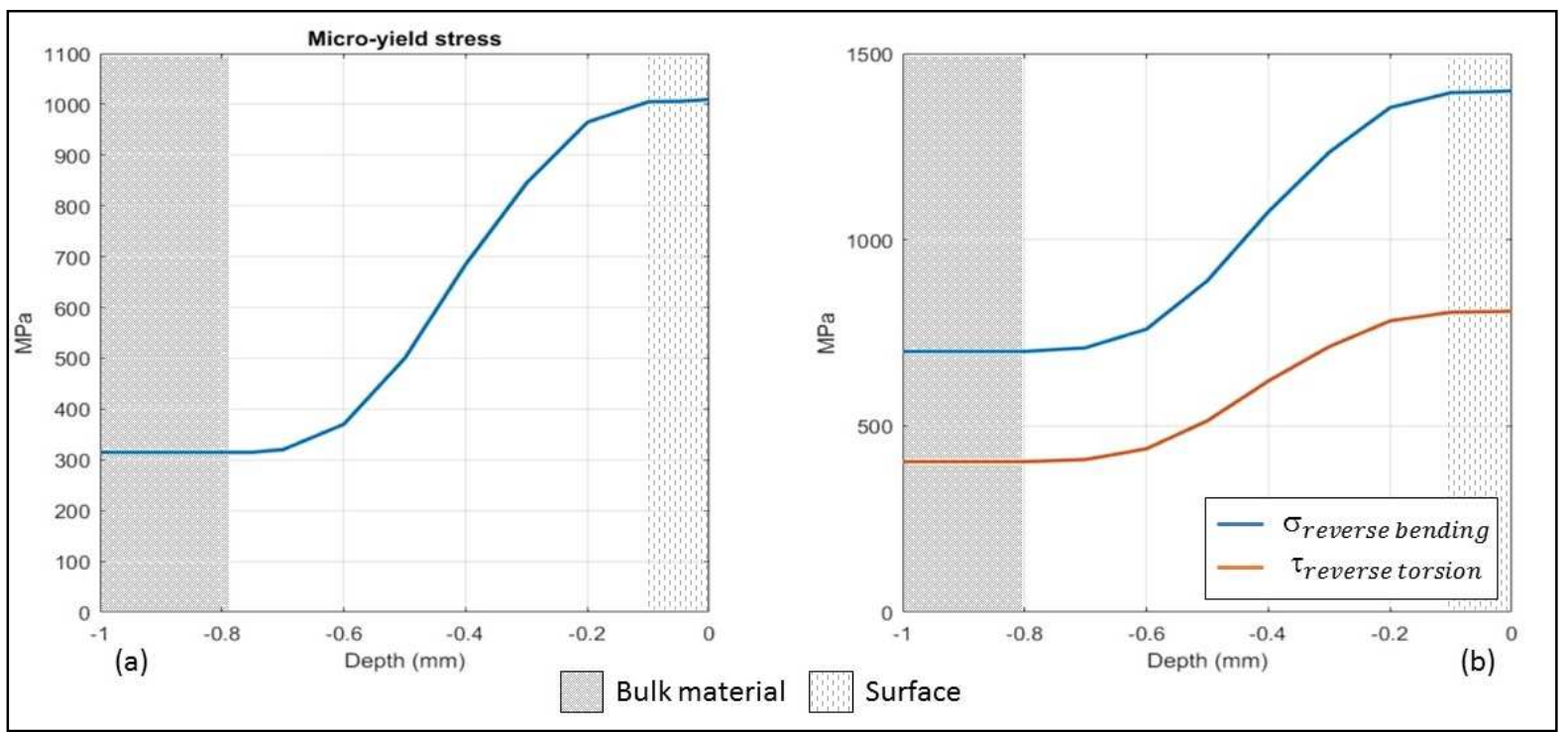

Figure 14 : Material properties of gas-nitrided steel a) Micro-yield stress b) reverse bending and torsion fatigue limits

Dang Van criterion is now calculated with these material parameters (Figure 14 (b)). Figure 15 shows simulation results. Dent impact on the surface and the Hertzian influence on the subsurface area are clearly observed. Since the criterion exceeds one, crack initiation should appear both at the surface and sub-surface.

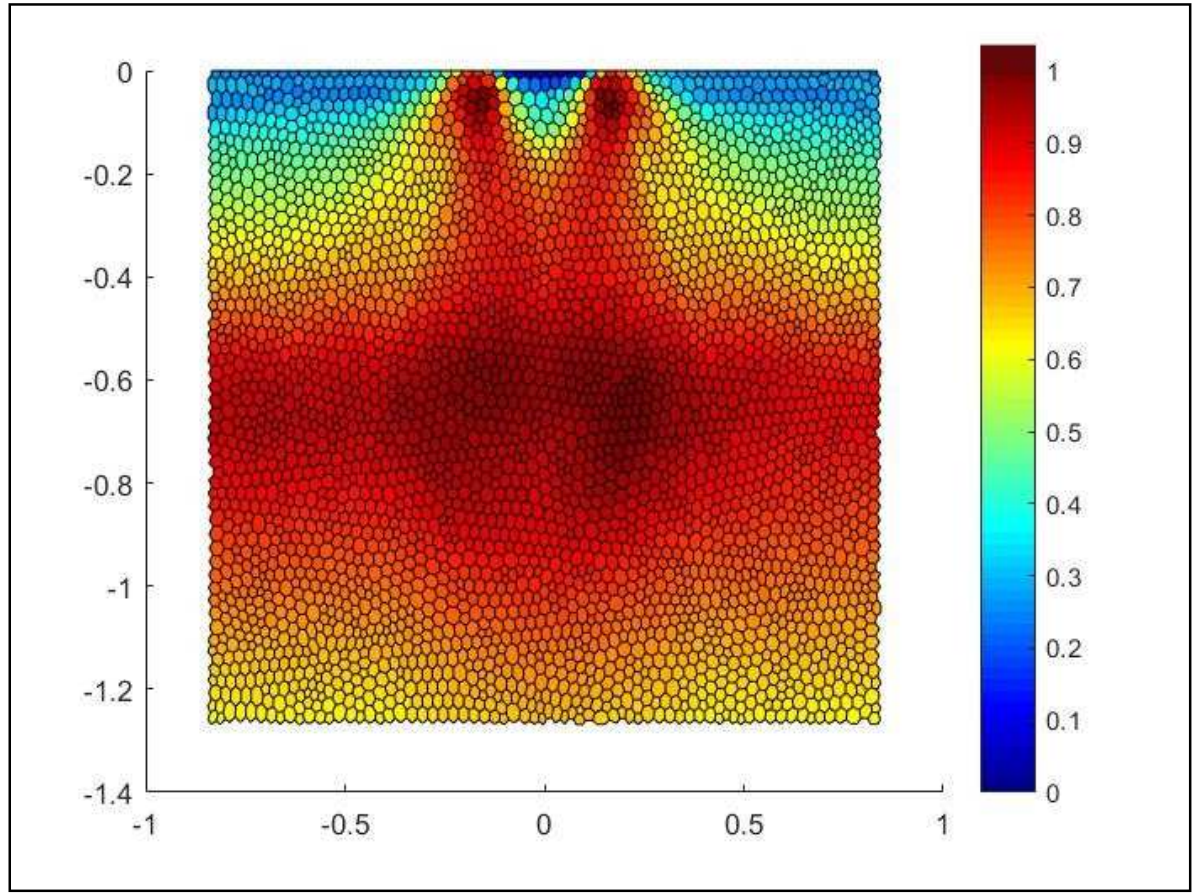

Figure 15 : Dang Van criterion for gas-nitrided steel

Figure 16 (b) shows the evolution of the dimensionless Dang Van criterion along the white path showed in Figure 16 (a) for bulk, surface and nitrided material properties. The result with 
the continuous variation of nitrided material properties, in black, is between the two curves of bulk and surface properties.

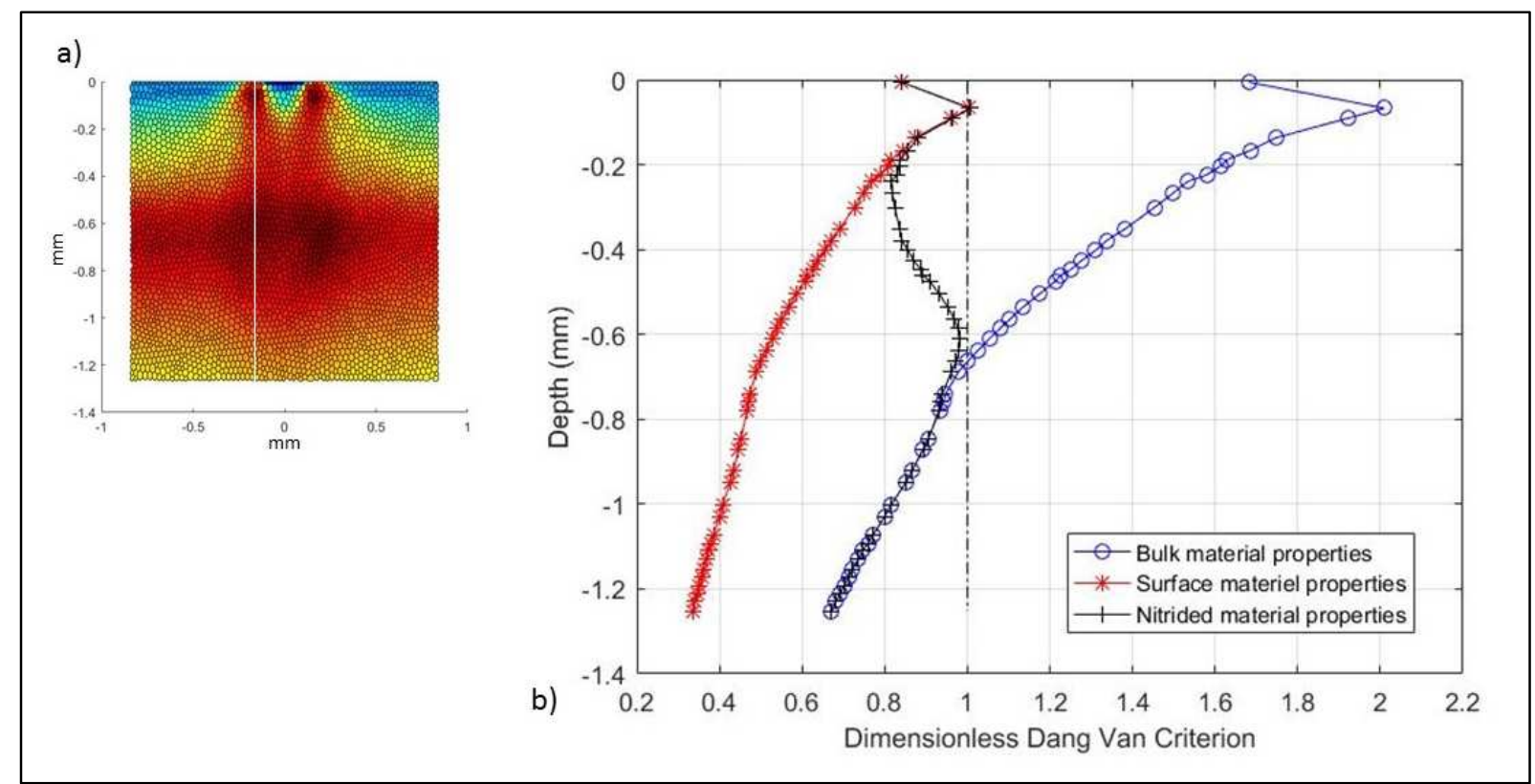

Figure 16 : a) Studied path, b) Dang Van criterion along the path

Figure 17 shows the same metallographic observation as Figure 7, 11 and 12, compared to the previous simulation. As in Figure 12, the dent at the surface induces a high value of the criterion (above one) between the black lines. It is clear that the crack initiates in this area, before propagating towards the core. DEA, which appears under the white line, corresponds here to the end of the surface properties and material decay due to RCF. Indeed, this depth corresponds to the zone where material parameters tend to get closer to the bulk. DEA are known to correspond to RCF [39] and this high value of Dang Van criterion can explain the appearance of this phenomenon. The same comparison can be made using the Tresca shear stress divided by the micro-yield stress, $\tau_{\text {Tresca }}^{\text {dimensionless }}$, Figure 18 . Once more, the end of the gas-nitrided treatment is observable. However, the Tresca shear stress is not a crack initiation criterion and the value being higher in the sub-surface $\left(\tau_{\text {Tresca }}^{\text {dimensionless }}=2\right.$ ) than at the surface $\left(\tau_{\text {Tresca }}^{\text {dimensionless }}=1.5\right)$, it cannot predict the experimental results as well as the Dang Van criterion does.

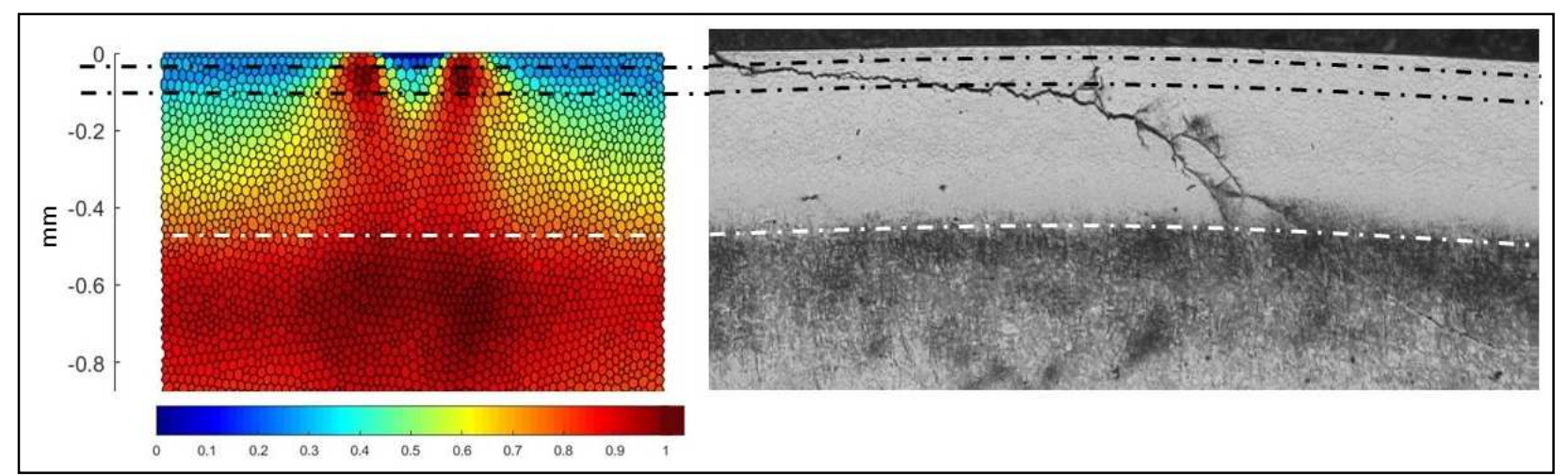

Figure 17 : Dang Van criterion calculation compared to experimental observations 


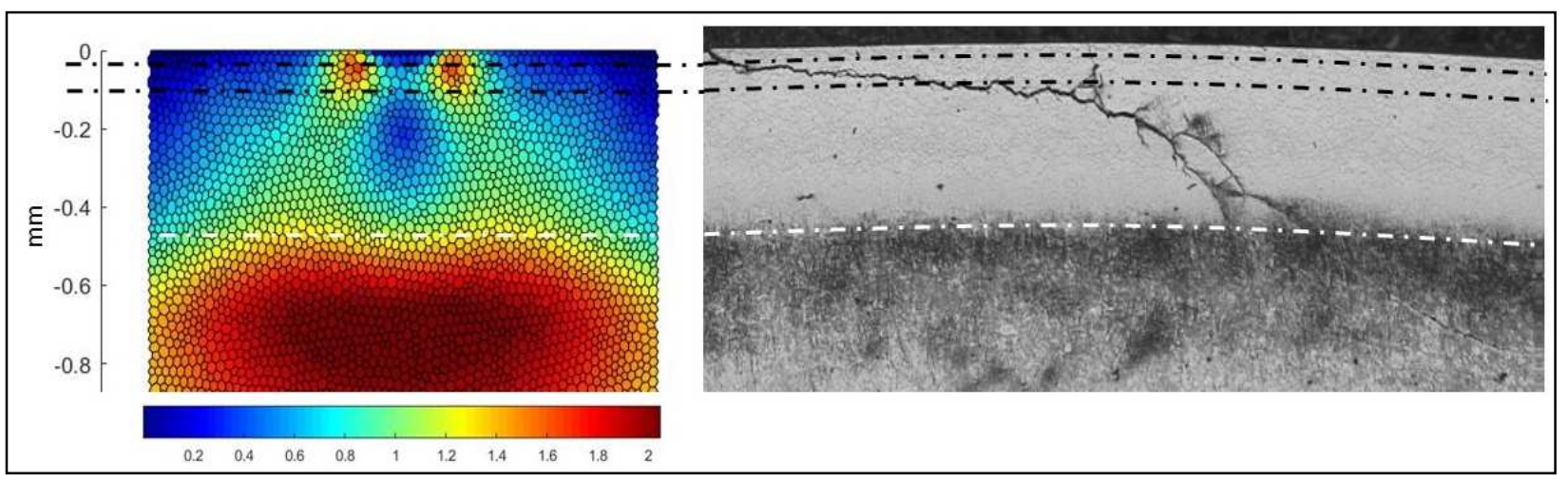

Figure 18: Dimensionless Tresca shear stresses compared to experimental observations - dent centred in $x=0$

\section{Conclusion}

In the present study, a numerical model for crack initiation within gas-nitrided steels subjected to RCF is developed and compared to experimental data. The FE simulation and the use of a multiaxial fatigue criterion are commonly used to predict the location of crack initiations for classical steel. However, gas-nitrided steel properties vary depending on depth. Using only the bulk core material properties or only hardened surface ones is not sufficient to predict the damage initiation observed experimentally. The proposed solution is to model this phenomenon based on the use of the micro yield stress profile to provide a realistic description of local fatigue resistance at the grain scale. With this method, the surface and sub-surface response to RCF are separated. Even if the use of the Dang Van criterion for RCF can be discussed [40], the model better predicts crack initiation in gas-nitrided mechanical components. Crack initiation seems to start within the near surface area, around $100 \mu \mathrm{m}$ deep in simulated conditions of this study. Then the cracks propagate in the case-hardened nitrided layer, eventually reaching the core. In order to confirm these hypotheses, crack initiation experiments with a similar protocol can be conducted. Furthermore, to improve the model, residual stresses due to gas-nitriding, although indirectly considered with the fatigue properties gradient, could additionally be taken into account.

\section{Acknowledgment}

The authors would like to thanks M. Le and J. Cavoret for the authorization of using their experiments. The participation of the IRT M2P and its partners is gratefully acknowledged as well.

\section{Reference}

[1] Olver, A. V., 2005, 'The Mechanism of Rolling Contact Fatigue: An Update', Proc. Inst. Mech. Eng. Part J J. Eng. Tribol., 219(5), pp. 313-330.

[2] Errichello, R. L., and Muller, J., 1994, 'PRODUCT FOCUS : GEARING How to Analyze Gear Failures PRODUCT FOCUS : GEARING', (March), pp. 35-40.

[3] Errichello, R., 2012, 'Morphology of Micropitting', Gear Technol., (December), pp. 74-81.

[4] Sadeghi, F., Jalalahmadi, B., Slack, T. S., Raje, N., and Arakere, N. K., 2009, 'A Review of Rolling Contact Fatigue', J. Tribol., 131(4), p. 041403.

[5] Lainé, E., Olver, A. V., and Beveridge, T. A., 2008, 'Effect of Lubricants on 
Micropitting and Wear', Tribol. Int., 41(11), pp. 1049-1055.

[6] Tallian, T. E., Brady, E. F., McCool, J. I., and Sibley, L. B., 1965, 'Lubricant Film Thickness and Wear in Rolling Point Contact', ASLE Trans., 8(4), pp. 411-424.

[7] Fabre, A., Evans, H. P., Barrallier, L., Sharif, K. J., and Desvignes, M., 2013, 'Prediction of Microgeometrical Influences on Micropitting Fatigue Damage on 32CrMoV13 Steel', Tribol. Int., 59, pp. 129-140.

[8] Lundberg, G., and Palmgren, A., 1949, 'Dynamic Capacity of Rolling Bearings', J. Appl. Mech. ASME, (16), pp. 165-72.

[9] Ioannides, E., and Harris, T. A., 1985, 'A New Fatigue Life Model for Rolling Bearingsle', J. Tribol., (107), pp. 367-377.

[10] Dang Van, K., Le Douaron, A., and Lieurade, H. P., 1984, 'Multiaxial Fatigue Limit: A New Approach'.

[11] Donzella, G., and Petrogalli, C., 2010, 'A Failure Assessment Diagram for Components Subjected to Rolling Contact Loading', Int. J. Fatigue, 32(2), pp. 256268.

[12] Octrue, M., Ghribi, D., and Sainsot, P., 2018, 'A Contribution to Study the Tooth Flank Fracture (TFF) in Cylindrical Gears', Procedia Eng., 213, pp. 215-226.

[13] Brandao de Sousa Ferreira, J. A., 2007, 'Gear Micropitting Prediction Using the Dang van High-Cycle Fatigue Criterion', MSc Thesis, p. 148.

[14] Brandão, J. A., Seabra, J. H. O., and Castro, J., 2010, 'Surface Initiated Tooth Flank Damage. Part II: Prediction of Micropitting Initiation and Mass Loss', Wear, 268(1), pp. 13-22.

[15] Brandão, J. A., Martins, R., Seabra, J. H. O., and Castro, M. J. D., 2015, ‘An Approach to the Simulation of Concurrent Gear Micropitting and Mild Wear', Wear, 324-325, pp. 64-73.

[16] Bernasconi, A., Davoli, P., Filippini, M., and Foletti, S., 2005, 'An Integrated Approach to Rolling Contact Sub-Surface Fatigue Assessment of Railway Wheels', Wear, 258(7-8), pp. 973-980.

[17] Antaluca, E., and Nélias, D., 2008, 'Contact Fatigue Analysis of a Dented Surface in a Dry Elastic-Plastic Circular Point Contact', Tribol. Lett., 29(2), pp. 139-153.

[18] Wang, W., Liu, H., Zhu, C., Wei, P., and Wu, W., 2019, 'Micromechanical Analysis of Gear Fatigue-Ratcheting Damage Considering the Phase State and Inclusion', Tribol. Int.

[19] Spies, H.-J., Thien, H. Le, and H. B, B., 2004, 'Controllend Nitriding', Met. Sci. Heat Treat., 46, pp. 23-25.

[20] TONICELLO, E., 2012, 'Etude et Modélisation de La Fatigue de Contact En Présence d'indentation Dans Le Cas de Roulements Tout Acier et Hybrides', pp. 1-143.

[21] Weil, H., Jégou, S., Barrallier, L., Courleux, A., and Beck, G., 2016, 'Fatigue Modelling for Gas Nitriding', Frat. ed Integrita Strutt., 10(38), pp. 61-66.

[22] Le, M., Ville, F., Kleber, X., Cavoret, J., Sainte-Catherine, M. C., and Briancon, L., 
2015, 'Influence of Grain Boundary Cementite Induced by Gas Nitriding on the Rolling Contact Fatigue of Alloyed Steels for Gears *', Proc. Inst. Mech. Eng. Part J J. Eng. Tribol., 229(8), pp. 917-928.

[23] Johnson, K. L., 1985, 'Contact Mechanics', J. Am. Chem. Soc., 37(22), pp. 1-17.

[24] Coulon, S., Jubault, I., Lubrecht, A. A., Ville, F., and Vergne, P., 2004, 'Pressure Profiles Measured within Lubricated Contacts in Presence of Dented Surfaces. Comparison with Numerical Models', Tribol. Int., 37(2), pp. 111-117.

[25] Labiau, A., Ville, F., Sainsot, P., Querlioz, E., and Lubrecht, A. A., 2008, 'Effect of Sinusoidal Surface Roughness under Starved Conditions on Rolling Contact Fatigue', Proc. Inst. Mech. Eng. Part J J. Eng. Tribol., 222(3), pp. 193-200.

[26] Morales-Espejel, G. E., Venner, C. H., and Greenwood, J. A., 2000, 'Kinematics of Transverse Real Roughness in Elastohydrodynamically Lubricated Line Contacts Using Fourier Analysis', Proc. Inst. Mech. Eng. Part J J. Eng. Tribol., 214(6), pp. 523534.

[27] Noyel, J. P., Ville, F., Jacquet, P., Gravouil, A., and Changenet, C., 2016, 'Development of a Granular Cohesive Model for Rolling Contact Fatigue Analysis: Crystal Anisotropy Modeling', Tribol. Trans., 59(3), pp. 469-479.

[28] Jean-philippe, N., 2015, 'Analyse de 1' Initiation de Fissures En Fatigue de Contact : Approche Mésoscopique'.

[29] Coulon, S., Ville, F., and Lubrecht, A. A., 2002, 'Effect of a Dent on the Pressure Distribution in Dry Point Contacts', J. Tribol., 124(1), p. 220.

[30] Hertz, H. R., 1882, 'Über Die Berührung Fester Elastischer Körper Und Über Die Härte', J. reine und angew.

[31] S.CoulonF.VilleA.A.Lubrecht, 2002, 'An Abacus for Predicting the Rolling Contact Fatigue Life Reduction Due to Debris Dentstle', Tribol. Ser.

[32] Ville, F., 1998, 'Pollution Solide Des Lubrifiants, Indentation et Fatigue Des Surfaces', INSA Lyon.

[33] Rabaso, P., Gauthier, T., Diaby, M., and Ville, F., 2013, 'Rolling Contact Fatigue: Experimental Study of the Influence of Sliding, Load, and Material Properties on the Resistance to Micropitting of Steel Discs', Tribol. Trans., 56(2), pp. 203-214.

[34] Le, M., 2015, 'Influence Des Liserés de Carbures Induits Par La Nitruration Gazeuse Sur Les Mécanismes de Fissuration de Fatigue de Contacts Roulants', INSA Lyon.

[35] Dang Van, K., Griveau, B., Message, O., and O. Message, 1989, 'On a New Multiaxial Fatigue Limit Criterion: Theory and Applications', Biaxial and Multiaxial Fatigue, 3, pp. 479-496.

[36] Chaussumier, M., 1999, 'Un Modèle Statistique de Calcul En Fatigue Multiaxiale Pour Les Pièces Mécaniques En Acier Nitruré', ENSAM.

[37] Barralis, J., and Castex, L., 1986, 'Improvement of Rotating Bending and Rolling Contact Fatigue of Nitrided 32CDV13'.

[38] Girodin, D., and Moraux, J. Y., 2002, 'L'acier 32CrMoV13 Nitruré Profond Pour Applications Aéronautiques', Trait. Therm., 341, pp. 27-32. 
[39] Zwirlein O and Shlicht H., 1982, 'Rolling Contact Fatigue Mechanisms - Accelerated Testing versus Field Performance', ASTM Int., (771), pp. 358-379.

[40] Desimone, H., Bernasconi, A., and Beretta, S., 2006, 'On the Application of Dang Van Criterion to Rolling Contact Fatigue', Wear, 260(4-5), pp. 567-572.

[2] Errichello, R. L., and Muller, J., 1994, 'PRODUCT FOCUS : GEARING How to Analyze Gear Failures PRODUCT FOCUS : GEARING', (March), pp. 35-40.

[3] Errichello, R., 2012, 'Morphology of Micropitting', Gear Technol., (December), pp. 74-81.

[4] Sadeghi, F., Jalalahmadi, B., Slack, T. S., Raje, N., and Arakere, N. K., 2009, 'A Review of Rolling Contact Fatigue', J. Tribol., 131(4), p. 041403.

[5] Lainé, E., Olver, A. V., and Beveridge, T. A., 2008, 'Effect of Lubricants on Micropitting and Wear', Tribol. Int., 41(11), pp. 1049-1055.

[6] Tallian, T. E., Brady, E. F., McCool, J. I., and Sibley, L. B., 1965, 'Lubricant Film Thickness and Wear in Rolling Point Contact', ASLE Trans., 8(4), pp. 411-424.

[7] Fabre, A., Evans, H. P., Barrallier, L., Sharif, K. J., and Desvignes, M., 2013, 'Prediction of Microgeometrical Influences on Micropitting Fatigue Damage on 32CrMoV13 Steel', Tribol. Int., 59, pp. 129-140.

[8] Lundberg, G., and Palmgren, A., 1949, 'Dynamic Capacity of Rolling Bearings', J. Appl. Mech. ASME, (16), pp. 165-72.

[9] Ioannides, E., and Harris, T. A., 1985, 'A New Fatigue Life Model for Rolling Bearingsle', J. Tribol., (107), pp. 367-377.

[10] Dang Van, K., Le Douaron, A., and Lieurade, H. P., 1984, 'Multiaxial Fatigue Limit: A New Approach'.

[11] Donzella, G., and Petrogalli, C., 2010, 'A Failure Assessment Diagram for Components Subjected to Rolling Contact Loading', Int. J. Fatigue, 32(2), pp. 256268.

[12] Octrue, M., Ghribi, D., and Sainsot, P., 2018, 'A Contribution to Study the Tooth Flank Fracture (TFF) in Cylindrical Gears’, Procedia Eng., 213, pp. 215-226.

[13] Brandao de Sousa Ferreira, J. A., 2007, 'Gear Micropitting Prediction Using the Dang van High-Cycle Fatigue Criterion’, MSc Thesis, p. 148.

[14] Brandão, J. A., Seabra, J. H. O., and Castro, J., 2010, 'Surface Initiated Tooth Flank Damage. Part II: Prediction of Micropitting Initiation and Mass Loss', Wear, 268(1), pp. 13-22.

[15] Brandão, J. A., Martins, R., Seabra, J. H. O., and Castro, M. J. D., 2015, 'An Approach to the Simulation of Concurrent Gear Micropitting and Mild Wear', Wear, 324-325, pp. 64-73.

[16] Bernasconi, A., Davoli, P., Filippini, M., and Foletti, S., 2005, ‘An Integrated Approach to Rolling Contact Sub-Surface Fatigue Assessment of Railway Wheels', Wear, 258(7-8), pp. 973-980. 
[17] Antaluca, E., and Nélias, D., 2008, 'Contact Fatigue Analysis of a Dented Surface in a Dry Elastic-Plastic Circular Point Contact', Tribol. Lett., 29(2), pp. 139-153.

[18] Wang, W., Liu, H., Zhu, C., Wei, P., and Wu, W., 2019, 'Micromechanical Analysis of Gear Fatigue-Ratcheting Damage Considering the Phase State and Inclusion', Tribol. Int.

[19] Spies, H.-J., Thien, H. Le, and H. B, B., 2004, 'Controllend Nitriding', Met. Sci. Heat Treat., 46, pp. 23-25.

[20] TONICELLO, E., 2012, 'Etude et Modélisation de La Fatigue de Contact En Présence d'indentation Dans Le Cas de Roulements Tout Acier et Hybrides', pp. 1-143.

[21] Weil, H., Jégou, S., Barrallier, L., Courleux, A., and Beck, G., 2016, 'Fatigue Modelling for Gas Nitriding', Frat. ed Integrita Strutt., 10(38), pp. 61-66.

[22] Le, M., Ville, F., Kleber, X., Cavoret, J., Sainte-Catherine, M. C., and Briancon, L., 2015, 'Influence of Grain Boundary Cementite Induced by Gas Nitriding on the Rolling Contact Fatigue of Alloyed Steels for Gears $\square$ ', Proc. Inst. Mech. Eng. Part J J. Eng. Tribol., 229(8), pp. 917-928.

[23] Johnson, K. L., 1985, ‘Contact Mechanics', J. Am. Chem. Soc., 37(22), pp. 1-17.

[24] Coulon, S., Jubault, I., Lubrecht, A. A., Ville, F., and Vergne, P., 2004, 'Pressure Profiles Measured within Lubricated Contacts in Presence of Dented Surfaces. Comparison with Numerical Models', Tribol. Int., 37(2), pp. 111-117.

[25] Labiau, A., Ville, F., Sainsot, P., Querlioz, E., and Lubrecht, A. A., 2008, 'Effect of Sinusoidal Surface Roughness under Starved Conditions on Rolling Contact Fatigue', Proc. Inst. Mech. Eng. Part J J. Eng. Tribol., 222(3), pp. 193-200.

[26] Morales-Espejel, G. E., Venner, C. H., and Greenwood, J. A., 2000, 'Kinematics of Transverse Real Roughness in Elastohydrodynamically Lubricated Line Contacts Using Fourier Analysis', Proc. Inst. Mech. Eng. Part J J. Eng. Tribol., 214(6), pp. $523-$ 534.

[27] Noyel, J. P., Ville, F., Jacquet, P., Gravouil, A., and Changenet, C., 2016, 'Development of a Granular Cohesive Model for Rolling Contact Fatigue Analysis: Crystal Anisotropy Modeling', Tribol. Trans., 59(3), pp. 469-479.

[28] Coulon, S., Ville, F., and Lubrecht, A. A., 2002, 'Effect of a Dent on the Pressure Distribution in Dry Point Contacts', J. Tribol., 124(1), p. 220.

[29] Hertz, H. R., 1882, 'Über Die Berührung Fester Elastischer Körper Und Über Die Härte', J. reine und angew.

[30] S.CoulonF.VilleA.A.Lubrecht, 2002, 'An Abacus for Predicting the Rolling Contact Fatigue Life Reduction Due to Debris Dentstle', Tribol. Ser.

[31] Ville, F., 1998, 'Pollution Solide Des Lubrifiants, Indentation et Fatigue Des Surfaces', INSA Lyon.

[32] Rabaso, P., Gauthier, T., Diaby, M., and Ville, F., 2013, 'Rolling Contact Fatigue: Experimental Study of the Influence of Sliding, Load, and Material Properties on the Resistance to Micropitting of Steel Discs', Tribol. Trans., 56(2), pp. 203-214.

[33] Le, M., 2015, 'Influence Des Liserés de Carbures Induits Par La Nitruration Gazeuse 
Sur Les Mécanismes de Fissuration de Fatigue de Contacts Roulants', INSA Lyon.

[34] Dang Van, K., Griveau, B., Message, O., and O. Message, 1989, 'On a New Multiaxial Fatigue Limit Criterion: Theory and Applications', Biaxial and Multiaxial Fatigue, 3, pp. 479-496.

[35] Barralis, J., and Castex, L., 1986, 'Improvement of Rotating Bending and Rolling Contact Fatigue of Nitrided 32CDV13'.

[36] Girodin, D., and Moraux, J. Y., 2002, 'L'acier 32CrMoV13 Nitruré Profond Pour Applications Aéronautiques', Trait. Therm., 341, pp. 27-32.

[37] Zwirlein O and Shlicht H., 1982, 'Rolling Contact Fatigue Mechanisms - Accelerated Testing versus Field Performance', ASTM Int., (771), pp. 358-379.

[38] Desimone, H., Bernasconi, A., and Beretta, S., 2006, 'On the Application of Dang Van Criterion to Rolling Contact Fatigue', Wear, 260(4-5), pp. 567-572. 